\title{
Emotional and Playful Stance Taking in Joint Play between Adults and Very Young Children
}

\section{Pursi, Annukka}

2018-09

Pursi , A , Lipponen , L \& Sajaniemi , N 2018 , ' Emotional and Playful Stance Taking in Joint Play between Adults and Very Young Children ', Learning, Culture and Social Interaction , vol. 18 , pp. 28-45 . https://doi.org/10.1016/j.Icsi.2018.03.002

http://hdl.handle.net/10138/319726

https://doi.org/10.1016/j.Icsi.2018.03.002

acceptedVersion

Downloaded from Helda, University of Helsinki institutional repository.

This is an electronic reprint of the original article.

This reprint may differ from the original in pagination and typographic detail.

Please cite the original version. 
This is the author's version of a work that was accepted for publication in the following source:

Pursi, A., Lipponen, L. \& Sajaniemi, N. (In press). Emotional and Playful Stance

Taking in Joint Play between Adults and Very Young Children. Learning, Culture and Social Interaction (2018).

\section{Emotional and Playful Stance Taking in Joint Play between Adults and Very Young}

\section{Children}

Pursi, A., Lipponen, L. \& Sajaniemi, N.

\section{Abstract}

The purpose of this single case study was to investigate emotional and playful stance taking in adults and very young children as they engage in joint make-believe play activity in a natural Finnish group-care setting. Drawing on the sequential approach of conversation analysis (CA), the study represents an effort to understand play in an early childhood education (ECE) setting from both children's and adults' perspectives at the same time. The results suggest that the interplay of emotional and playful stance taking in make-believe play produces emotional transitions in interaction. These transitions can be understood as interactional accomplishments that offer children and adults the possibility to align and affiliate themselves with their own and each other's emotional experiences and to explore personal reflections of the emotionally heightened real-life trajectories in a shared makebelieve play frame. Based on these findings, it is argued that creating and maintaining emotionally heightened joint play with very young children requires adults' emotional involvement and delicately calibrated participation through leading, following and leading by following. Further empirical study is needed to investigate sequences in which playful and emotional stance taking stand in a non-aligning and non-affiliating relationship. Such research could reveal problem-remedy sequences more evidently and provide important further development of ECE theory and practice for children under the age of three. Keywords: play; emotion; stance; joint activity; adult-child interaction 


\section{Introduction}

Joint play activity is an interesting phenomenon in terms of both analysis of social interaction and study of emotion. Play and emotion seem to be closely intertwined and many scholars have stated that a deeper understanding of play must consider the elaboration of its emotional underpinnings (Burghardt, 2005; Howard \& McIness, 2013; Kuczaj \& Horback, 2013). Empirical interaction research has shown that displays of positive emotion and play are highly correlated and there has been a continuing tradition of integrating emotional characterizations into the definition of play. For instance, pleasure, enjoyment, joy and amusement displayed through smiling, laughter and other non-verbal and verbal resources have been commonly mentioned emotional characteristics of play and play signaling (Burghardt, 2011; Darwin, 1872/1965). On the other hand, studies have also pointed out that play can be serious and produce a sort of mirror or interactional space for a wide range of emotional tones and nuances that emerge from real-life trajectories and relationships (Bateman, Danby \& Howard, 2013; Björk-Willén, 2012; Cobb-Moore, 2012).

Especially make-believe play - a form of activity that involves transformation of ordinary objects and persons into characters in a fictional world (Garvey, 1976) - is often described as an activity in which emotions are in continuous flux and also negative emotions can be displayed in as if form through play signals (Bateson, 1976). A wide corpus of empirical interaction studies support these claims regarding the emotional complexity of make-believe play. Studies on children's play in peer groups have reported 'playful' displays of anger and aggression in activities such as play fighting (Smith, 1997), exploration of different kinds of negative tones (e.g., playful disputes) embedded in family role-play (Aronsson \& Thorell, 1999; Björk-Willén, 2012; Cobb-Moore, 2012) and forms of 'playful' unkindness within activities such as mocking and teasing (Lerner \& Zimmerman, 2003). 
It is evident that emotions are pervasive elements of play, however we still know relatively little about the actual structures and processes of emotions in play interaction. More detailed and systematic research is needed especially in the field of early childhood education, where play is considered to be the basic feature of everyday interactions (Singer, 2013). Existing literature has mainly explored the connection between play and emotions from a psychological or educational perspective and focused on demonstrating the functional significance of play for the individual child and his/her socio-emotional development and learning (for an overview see Pyle, DeLuca \& Danniels, in press). Considerably less attention has been paid to relational and interactional perspectives, such as exploring how emotions emerge and unfold in joint play activities and how different kinds of emotions inform, affect, direct and coordinate children's and adults' actions during play activities (cf. Madrid, Fernie \& Kantor, 2015; White, 2013).

In this single case analysis (Sacks, 1984; Schegloff, 1987) we investigate emotional and playful stance taking in adults and very young children as they engage in joint makebelieve play activity in a natural Finnish group-care setting. More specifically, we are interested in how adults' playful and emotional stance taking contribute to taking turns and to the larger play activity context. In our approach emotions and play are understood as stance displays (Goodwin, Cekaite \& Goodwin, 2012) and more dynamically as stance shifts, for example from more serious and real to playful or from more neutral to emotional (Kaukomaa, Peräkylä \& Ruusuvuori, 2015; Pursi \& Lipponen, in press). The central methodological assumption underlying our study is that by positioning play and display of emotion in the same analytical frame and analyzing them as "different facets of a single unified stance act" (Du Bois, 2007, 145), we might be able to learn something new about both, and about the relationship between them. 
While stance, like make-believe play and emotion, has been treated as an attitudinal matter and psychological feature of an individual person ("pretense can occur in the absence of pretense actions, but not in the absence of mental representations" Lillard, 1993, 373), in this paper we align with a different appreciation of these phenomena. We view stance taking as a publicly available system and as a form of social interaction. Like recent interactional studies, we conceptualize stance taking as both a subjective and an intersubjective act through which individuals align themselves in relation to themselves, each other and the ongoing courses of action (Du Bois, 2007; Goodwin, 2007). In other words, a stance as congruent or incongruent alignment "refers to the distance from or closeness to the experience" (Stern, 2004, 39), including both subjective and shared experiences.

Previous studies have illustrated how joint make-believe play emerges between adults and very young children in natural group-care settings and how adults organize their actions to actively participate in shared make-believe activity (Bateman, 2015; Jung, 2013; Lobman, 2006; Pursi \& Lipponen, in press). However, so far, no empirical studies have systematically focused on investigating co-coordination and interactional calibration of emotion in joint play between adults and very young children. One way to study and describe these phenomena is to detect emotionally heightened moments from naturally occurring joint play interaction and systematically investigate how emotions arise in the first place, how emotional and playful stance taking unfold towards shared emotionally heightened moments and finally how heightened emotions and play 'disappear' from the interaction. In interactional studies this kind of analysis is called a sequential approach. In this paper, we draw mainly on the sequential perspective of conversation analysis (CA) and its treatment of joint activity, makebelieve play, stance and emotion (Du Bois \& Kärkkäinen, 2012; Goodwin, 2007; Sidnell, 2011). 
Our analytical interest focuses exclusively on those aspects of play and emotion that the interactants make publicly available (through verbal and non-verbal means). We assume that play actions are lodged to the sequential organization of unfolding interaction and therefore cannot be examined in isolation from their interactional context. We demonstrate how playful and emotional stance taking is organized between adults and very young children during one, emotionally heightened joint play sequence taken from a larger corpus of videotaped data $(150 \mathrm{~h})$. More specifically, we answer the following research questions:

1. How do the adults and very young children construct and organize their emotional and playful stance taking during one sequence of emotionally heightened joint make-believe play?

2. How does the adults' playful and emotional stance taking contribute to taking turns and to the larger play activity context during one sequence of emotionally heightened joint makebelieve play?

3. How do the adults and children open, sustain and close the emotionally heightened joint play sequence?

\section{Methodological considerations}

\subsection{Context of the study}

This article offers a single case analysis (Sacks, 1984; Schegloff, 1987) of one emotionally heightened play sequence in which an adult and a group of children are mutually engaged in joint make-believe play activity. The video-recorded sequence is part of a larger ethnographic study examining play culture and especially adults' and children's joint play activity in one Finnish toddler classroom. The classroom was a municipal group-care setting for 13 children under the age of three with one qualified kindergarten teacher, two qualified nursery nurses and one personal assistant to a child with special needs (adult-child ratio 1:4). 
The day care center was located in an outer suburb of Helsinki, Finland. This particular toddler group was chosen because initial short-term observations revealed that adults frequently co-participated in children's play activities and also actively initiated joint play during adult-led activities. Overall, the adults' interaction was responsive and improvisational (cf. Lobman, 2006), offering a rich context to examine joint play activity between adults and children.

During the data collection period, the researcher was a non-participant observer, intending to disrupt the everyday life of the group as little as possible (Løkken, 2011). Interaction was video-recorded mainly at floor level using one handheld camera. The videoobservation method was chosen, since video recordings allowed for the study of fine-grained temporal and embodied details of joint play interaction that would have been difficult to notice without repeated viewings. The camera was focused on the interactants (toddlers and adults) and interaction was recorded whenever there was evidence of joint play activity between adults and toddlers. Occasionally other sequences of joint action and play (children's solitary and parallel play, joint play among peers, adults' and children's joint conversations etc.) were recorded in order to be able to detect potential and more sudden or subtle shifts into the joint play activity. In this way it was possible to record full joint play sequences with openings, progressions and closings.

By focusing on the analysis of one rich case (Patton, 1990) the aim was to explore in detail the complexity of emotionally heightened joint play between adults and children, describe systematic features of multi-party play interaction and explicate the participants' methods of making the situation what it becomes. According to C. Goodwin (1994), single case studies that illustrate the particularity of the case are invaluable if the practice in question is highly complex or socially significant. In a natural group-care setting adults' active participation in play is highly complex, multidimensional and somewhat equivocal 
practice. Overviews of existing literature show a lack of consensus in both research and practice regarding the value and role of play in the pedagogical relationships between adults and children (Pyle et al., in press). Thereby, data-driven single case approaches that provide access to the actual practice in which joint play is accomplished and sustained between adults and children may clarify and extend the understanding of play in pedagogical relationships (Bateman, 2015; Pursi \& Lipponen, in press).

The kindergarten teacher of the group informed all the families about the videoobservation research and their rights to choose not to participate. In accordance with contemporary ethical guidelines (Finnish Advisory Board on Research Integrity), informed consent was sought from parents, ECE practitioners, the director of the day-care center and the municipality officials. As the video-observation method and long-term fieldwork raised specific ethical considerations, careful attention was paid to the situated ethics (see, Pursi \& Lipponen, in press). After the data collection, parents and ECE practitioners signed consent forms permitting the use of the material (e.g., frame grabs from the video data) for research and educational purposes. At that time, all the participants were given the opportunity to see some parts of the data.

\subsection{The ethnographic context of joint play between adults and children during whole-group circle time}

Our primary data consists of an emotionally heightened joint play sequence between adults and a group of toddlers during a circle time. By selecting a whole-group circle time as our context we were able to systematically focus on the multi-party environment. This was important in terms of extending the current understanding of play in a natural group-care setting, because previous studies have mostly reported analysis of adult-child dyads or group interactions of an adult and two to three children (Bateman, 2015; Jung, 2013, for a notable exception see Lobman, 2006). 
In the context of this study, circle time was an adult-led whole-group activity. Typically, one of the adults led the activity and the other adults provided individual support for the children to maintain their attention during the joint activity. There was one compulsory circle time for all children before lunch and it lasted approximately 10-25 min. A circle time comprised singing, making music together, storytelling, improvised joint play and conversational sharing of moods, ideas, experiences, and so on. It was characteristic for this interactional context that the shifts from adult-led activity to playful conversations and back again were very smooth. Moreover, during the conversational moments any topic could be introduced by the children, for example, a comment that makes an individual activity an interactional concern, or some reference to an object in the surroundings or to an embodied action in progress. The adult who was leading the circle time was oriented to acknowledge these initiatives and elaborated them further by providing improvisational 'yes, and' offers (Lobman, 2006). Table 1 outlines the primary data of this study and the creation of data sources in more detail. 
Table 1. Creation of data sources

\begin{tabular}{|c|c|c|c|}
\hline Fieldwork 2013-2016 & Circle time & $\begin{array}{l}\text { Joint play } \\
\text { activity }\end{array}$ & Single case analysis \\
\hline $\begin{array}{l}\mathbf{1 5 0} \text { h of video- } \\
\text { observations } \\
38 \text { days of full-day } \\
\text { observations }\end{array}$ & $\begin{array}{l}\mathbf{1 7} \mathbf{~ m i n} \\
\text { Circle time activity } \\
\text { between three } \\
\text { adults and } 11 \\
\text { toddlers. }\end{array}$ & $\begin{array}{l}\mathbf{3} \text { min } 28 \mathbf{s} \\
\text { A total of } 5 \\
\text { joint play } \\
\text { sequences } \\
\text { during the } \\
\text { circle time. }\end{array}$ & $\begin{array}{l}1 \text { min } 45 \mathrm{~s} \\
\text { Sustained, } \\
\text { emotionally } \\
\text { heightened joint play } \\
\text { sequence during the } \\
\text { circle time. }\end{array}$ \\
\hline $\begin{array}{l}\text { What is going on? Is there } \\
\text { play in the interaction? } \\
\text { What, when and how is it } \\
\text { said and done in joint play } \\
\text { interaction between adults } \\
\text { and children? }\end{array}$ & $\begin{array}{l}\text { What happened } \\
\text { before emotionally } \\
\text { heightened joint } \\
\text { play and what } \\
\text { followed after it } \\
\text { between the adults } \\
\text { and children? }\end{array}$ & $\begin{array}{l}\text { How is joint } \\
\text { play activity } \\
\text { created and } \\
\text { maintained } \\
\text { during the } \\
\text { circle time? }\end{array}$ & $\begin{array}{l}\text { How do children and } \\
\text { adults open, sustain } \\
\text { and close the } \\
\text { emotionally } \\
\text { heightened joint play } \\
\text { sequence? }\end{array}$ \\
\hline $\begin{array}{l}\text { Searching for sequences } \\
\text { in which adult(s) and at } \\
\text { least three toddlers are } \\
\text { mutually engaged in joint } \\
\text { play activity and they } \\
\text { make use of talk and } \\
\text { embodied resources, such } \\
\text { as gestures, facial } \\
\text { expressions, body } \\
\text { postures and prosody to } \\
\text { build heightened emotive } \\
\text { involvement. }\end{array}$ & $\begin{array}{l}\text { Sampling: All the } \\
\text { joint play } \\
\text { sequences during } \\
\text { the circle time. }\end{array}$ & $\begin{array}{l}\text { Analysis: } \\
\text { Narrative } \\
\text { descriptions, } \\
\text { detailed } \\
\text { transcripts and } \\
\text { sequential } \\
\text { analysis of joint } \\
\text { play activity. }\end{array}$ & $\begin{array}{l}5 \text { extracts of the data } \\
\text { are analyzed in this } \\
\text { paper. Opening, } \\
\text { sustainment and } \\
\text { closing of the joint } \\
\text { play sequence is } \\
\text { illustrated by } \\
\text { combining verbal } \\
\text { descriptions, frame } \\
\text { grabs and } \\
\text { transcriptions. }\end{array}$ \\
\hline
\end{tabular}

\section{Data analysis}

The analysis was guided by two questions: how emotional stance shifts emerge within joint make-believe play interaction and what kind of social consequences these emotional stance shifts have for the ongoing play activity and its social organization. In our analysis we divided joint play activity into three sequential units: 1) play signaling (playful stance taking), 2) play connection (shared playful stance taking) and 3) sustained co-participation. According to our sequential understanding, when playful interaction opens, the organization of the first two moves will show whether the interaction is play or not. An initial move of joint play is 
called a play signal. Through play signals (Bateson 1976; Garvey 1976), players

communicate their playful stance to others in order to initiate and maintain joint play activity (Pursi \& Lipponen, in press). Relying on different verbal and non-verbal interactional resources, players make the message, 'this is play', publicly available. A second move is a response to a play signal. A play connection is constituted if the recipients of the play signal display alignment with the play activity and affiliation with the player's stance (Pursi \& Lipponen, in press).

According to our use of analytical terminology, alignment relates to the structural level (e.g., an attentional display, body orientation, gaze direction) and affiliation to the affective or action level (e.g., emotional display, play actions) of joint activity (Stivers, 2008) and both aspects are needed for joint play to be manifest. In this sense, joint play activity can be understood as a complex interactional accomplishment that involves co-coordinated, shared playful stance taking in which the significance of particular play actions are situated and depend on the social context in which they are negotiated (Björk-Willén, 2012). Thereby, 'what is play or not is an interactional problem rather than a taxonomical one' (Butler, 2008, 79).

We define emotional stance taking during joint play as an interactive sequence in which a participant displays a shift in emotional stance from neutral to affective (Kaukomaa et al., 2015) while simultaneously communicating playful stance through play signaling. The stance shift is taken towards a more emphatic style, which is more-than-neutral affective stance that may be interpretable as suggesting a particular emotion (Selting, 1994, 2010). Shared emotional stance taking is constituted when other participants in the ongoing play align and affiliate with the displayed emotional stance. An emotionally heightened moment follows if the participants are displaying their shared emotional stance in overlap. Table 2 outlines more specific analytical questions and practices guiding our work. 
Table 2. Emotional stance taking in joint play

\begin{tabular}{|c|c|c|}
\hline $\begin{array}{l}\text { Joint play } \\
\text { activity }\end{array}$ & Emotional stance taking & $\begin{array}{l}\text { Interaction analysis in practice } \\
\text { (observability) }\end{array}$ \\
\hline Play signaling & $\begin{array}{l}\text { Does the play signal include } \\
\text { emotional stance? } \\
\text { If yes: What is the stance object? } \\
\text { Who is the stance leader? } \\
\text { To whom is the emotional stance } \\
\text { directed? }\end{array}$ & $\begin{array}{l}\text { By identifying how verbal and non- } \\
\text { verbal interactional resources are } \\
\text { used to make play actions and } \\
\text { emotional stance shifts observable } \\
\text { and recognizable to others. }\end{array}$ \\
\hline $\begin{array}{l}\text { Play } \\
\text { connection }\end{array}$ & $\begin{array}{l}\text { How do participants achieve a } \\
\text { congruent alignment in play? } \\
\text { How do participants share their } \\
\text { emotional stances? }\end{array}$ & $\begin{array}{l}\text { By identifying congruent alignments } \\
\text { in the arrangement of different verbal } \\
\text { and non-verbal practices and in the } \\
\text { form, intensity and timing of play } \\
\text { actions. }\end{array}$ \\
\hline $\begin{array}{l}\text { Sustained } \\
\text { co- } \\
\text { participation } \\
\text { in play }\end{array}$ & $\begin{array}{l}\text { How do participants interpret and } \\
\text { contribute to each other's emotional } \\
\text { stances during sustained play } \\
\text { interaction? } \\
\text { How is the dynamic process of } \\
\text { stance leading and following } \\
\text { constructed in play interaction? }\end{array}$ & $\begin{array}{l}\text { By identifying how previous, current, } \\
\text { and following components of a } \\
\text { sequential organization interlock and } \\
\text { reinforce one another in play } \\
\text { interaction. }\end{array}$ \\
\hline
\end{tabular}

In our analysis of adults' active participation in play we build on previous work (in particular Bateman, 2015; Lobman, 2006) to show how playful and emotional stance taking in adults and very young children can be co-operatively constructed. We use the concepts of stance leading, following and leading by following to describe adults' contribution to the stance taking act. Whereas leading means adults' active play signaling and following means alignment and affiliation with children's play signals, leading by following is defined as a practice in which the turn-constructional unit produced by the adult includes both stance following and leading, constituting what theories of improvisation define as 'yes, and' offers (Lobman, 2006). In this kind of organization of action the adult is recognizably implementing two different purposes within every turn. First, he or she is aligning with the children's ideas (saying yes) and then somehow elaborating them further (saying and). This improvisational 
practice has been found to be a responsive way for adults to actively participate in play and sustain shared engagement in group activities (Lobman, 2006). Nevertheless, the interplay of emotional and playful stance taking during this kind of practice has not yet been investigated. Adults' and children's joint play interaction was transcribed using the conventions of Jefferson (2004) described in the appendix. As the embodied actions of participants were important for the analysis, these were treated as turns in their own right (Goodwin, 2000) and represented using a combination of frame grabs, transcription, and verbal description. During the analysis, verbal descriptions alone were problematic because of their highly exclusive focus. We noticed that the initial observations and verbal descriptions focused on a few leading participants of the joint play activity, usually on adult-child dyads, whereas the transcripts displayed the different forms of participation of multiple actors and revealed complex, multi-party engagements (Erickson, 2010). The transcripts and repeated viewings of the video data confirmed, specified, altered and corrected the initial interpretations. Yet transcripts alone were not able to represent all the joint play actions, especially their embodied features, as they unfold in moment-to-moment interaction (Goodwin, 2000). In these situations verbal descriptions and frame grabs were an effective way of illustrating the observations, because they provided an overview of the visual aspects of the interaction.

In the following we will analyze in detail first the opening of joint play (3.1), then progression of joint play and development of the emotionally heightened moment (3.2) and finally the closing of play (3.3). In the illustrations of the data all the names of the children have been changed to preserve anonymity. To improve the readability of the text, we use the term adult instead of pseudonyms to refer to the ECE practitioners. Table 3 outlines the overall organization of joint play between adults and children during a circle time. As we can see from the table, the joint play was fragmented and organized in short segments $(6 \mathrm{sec}-1$ $\min 45 \mathrm{sec}$ ). The observations also indicate that redirections to the other activities, 
interruptions and re-establishments of joint play were common features of this particular play setting.

Table 3. The organization of joint play between adults and children during a circle time

A whole-group circle time between 11:09 a.m. and 11:26 a.m. (17 min):

Sing-along, joint music making, conversations and joint play

\begin{tabular}{|c|c|c|c|c|}
\hline $\begin{array}{l}\text { First moment } \\
\text { of play } \\
\text { connection } \\
11: 20 \text { a.m. } \\
(40 \mathrm{~s})\end{array}$ & $\begin{array}{l}\text { Second moment } \\
\text { of play } \\
\text { connection } \\
11: 22 \text { a.m. } \\
(44 \mathrm{~s})\end{array}$ & $\begin{array}{l}\text { Third moment } \\
\text { of play } \\
\text { connection } \\
11: 23 \text { a.m. } \\
(6 \mathrm{~s})\end{array}$ & $\begin{array}{l}\text { Sustained, } \\
\text { emotionally } \\
\text { heightened } \\
\text { joint play } \\
11: 23 \text { a.m. } \\
(1 \text { min } 45 \mathrm{~s})\end{array}$ & $\begin{array}{l}\text { Closing of } \\
\text { joint play } \\
11: 25 \text { a.m. } \\
(13 \mathrm{~s})\end{array}$ \\
\hline $\begin{array}{l}\text { The adult } \\
\text { animates the } \\
\text { sound of a } \\
\text { rooster. } \\
\text { Children } \\
\text { respond with } \\
\text { smiles and } \\
\text { short bursts of } \\
\text { laughter. Some } \\
\text { of the children } \\
\text { participate by } \\
\text { animating the } \\
\text { sound. Then } \\
\text { the adult } \\
\text { redirects the } \\
\text { group to the } \\
\text { sing-along } \\
\text { activity. }\end{array}$ & $\begin{array}{l}\text { The adult } \\
\text { animates the } \\
\text { sound of a } \\
\text { sheep. Children } \\
\text { respond with } \\
\text { smiles and } \\
\text { bursts of } \\
\text { laughter. Then } \\
\text { the adult } \\
\text { redirects the } \\
\text { group to the } \\
\text { sing-along } \\
\text { activity. } \\
\text { (Extract 1) }\end{array}$ & $\begin{array}{l}\text { The adult and } \\
\text { children animate } \\
\text { the sound of the } \\
\text { sheep together. } \\
\text { Joint play is } \\
\text { interrupted } \\
\text { because of a } \\
\text { dispute between } \\
\text { two children in } \\
\text { which the adult } \\
\text { intervenes. } \\
\text { (Extract 2) }\end{array}$ & $\begin{array}{l}\text { One of the } \\
\text { children re- } \\
\text { establishes the } \\
\text { play connection } \\
\text { and the adult } \\
\text { aligns and } \\
\text { affiliates. The } \\
\text { progression of } \\
\text { play is co- } \\
\text { operatively } \\
\text { constructed. } \\
\text { (extracts } \mathbf{2 , 3 , 4 ,} \\
\mathbf{5})\end{array}$ & $\begin{array}{l}\text { The adult } \\
\text { closes the joint } \\
\text { play sequence } \\
\text { while children } \\
\text { have begun } \\
\text { their transition } \\
\text { from circle } \\
\text { time to the } \\
\text { lunch hall. } \\
\text { One of the } \\
\text { children } \\
\text { witnesses the } \\
\text { closing of } \\
\text { play. } \\
\text { (Extract 5) }\end{array}$ \\
\hline
\end{tabular}

\subsection{Opening the interactional space for playful and emotional stance taking}

During the circle time, before the emotionally heightened joint play sequence that is at the center of our analysis (described in extracts 2, 3,4 and 5), the adult and the children had been discussing the subject of farm animals, singing thematically relevant songs and examining song-related toys (a barn, toy tractor, plastic rooster, and fluffy sheep) presented by the adult. Notably, the adult took a playful stance (play signaling) during the conversations 
and framed the interaction towards make-believe play by mimicking the sounds of the animals and manipulating the toy figures as if they themselves were moving. In these situations most of the children became more attentive and some joined in the adult's voice animations. Even the youngest ones (e.g., 16-month-old Venla) tried to emulate the sounds by modulating their vocalizations to the rhythm of the animations. Extract 1 illustrates one of these play signaling sequences and the establishment of play connection that follows. This sequence also demonstrates how different kinds of alignments and affiliations become publicly available in the multi-party joint play activity context.

\section{Extract 1.}

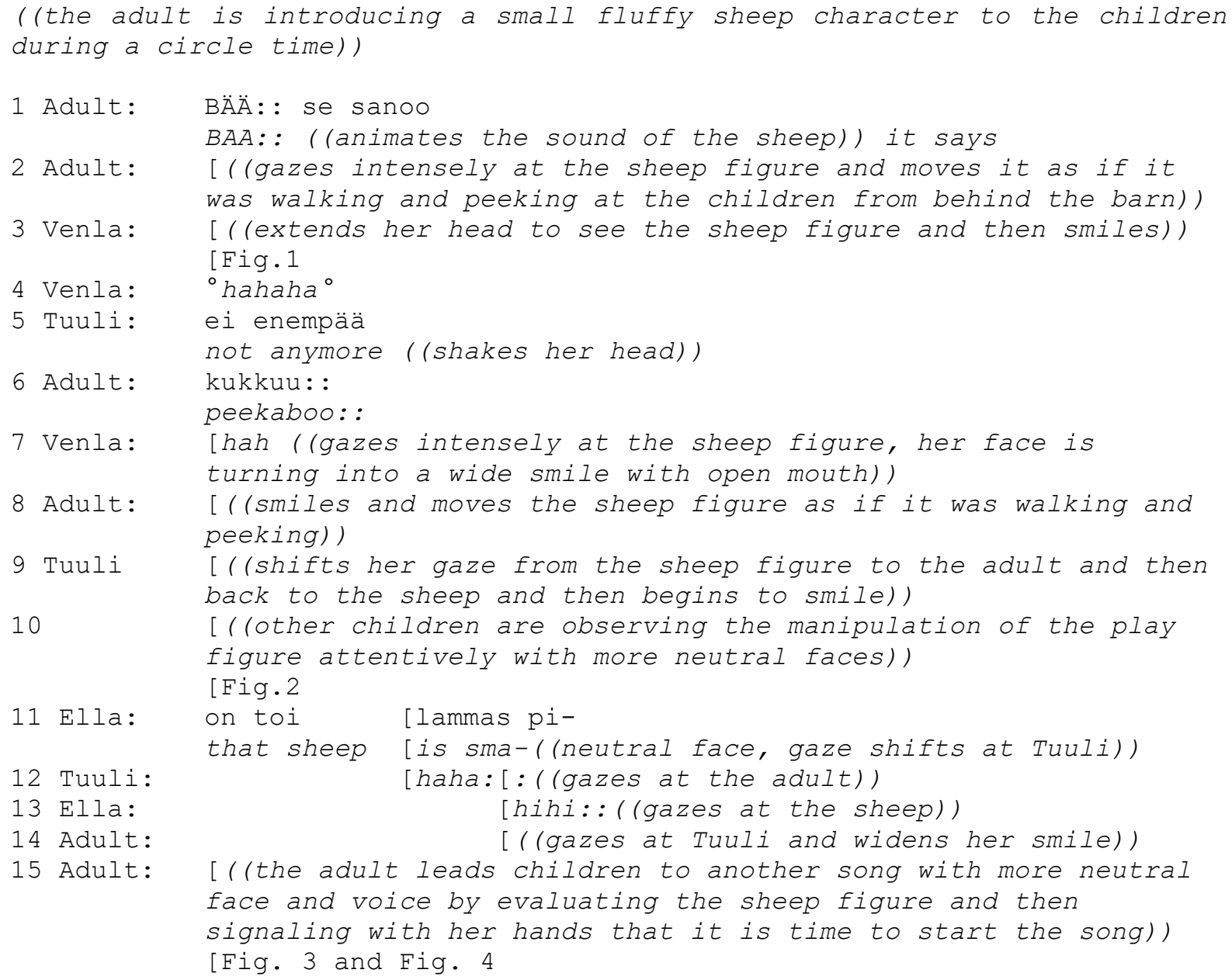



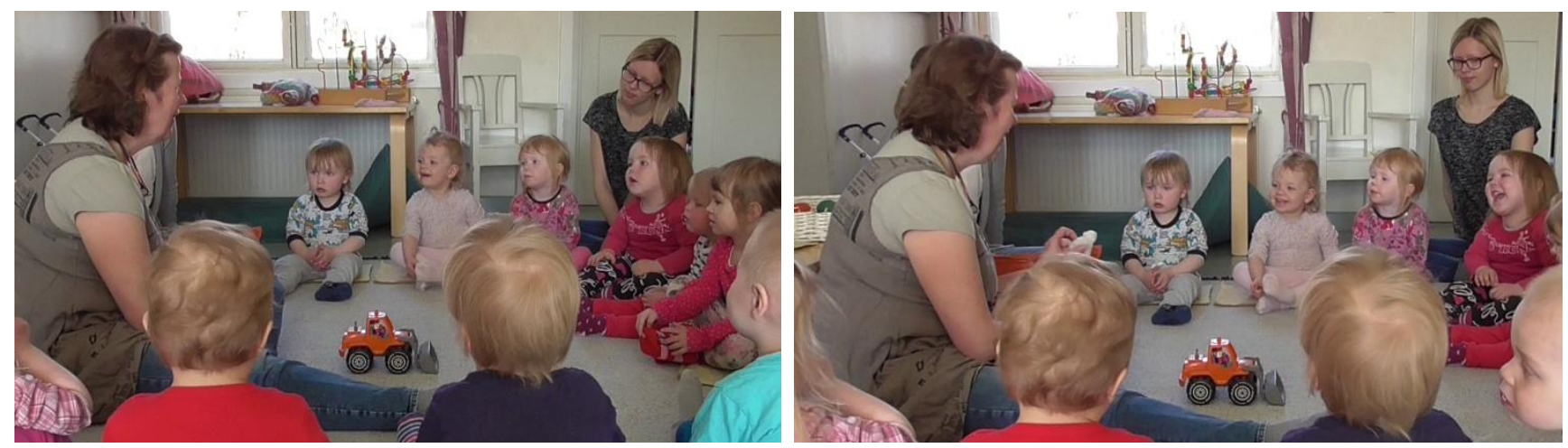

Fig. 1 \& 2. From an adult's play signaling towards emotionally heightened joint play
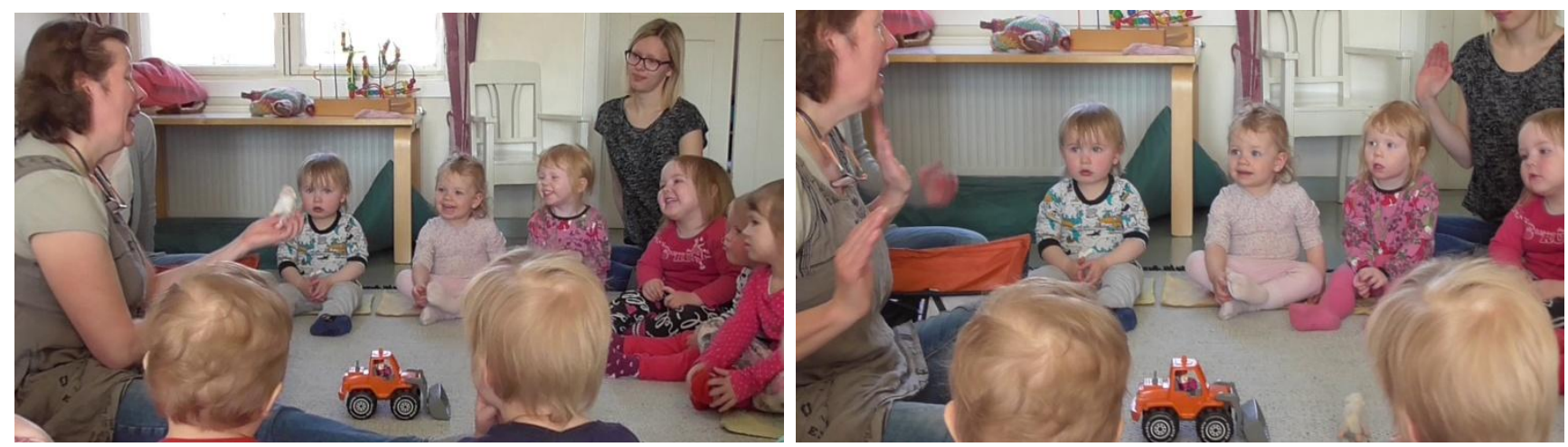

Fig. 3 \& 4. Activity shift from emotionally heightened joint play towards sing-along

In lines $1-2$, rather than framing the interaction towards an educational context by asking for example 'what does the sheep say' or by explicitly teaching that 'the sheep says BAA', the adult is producing a multimodal play signal by simply beginning the play activity (Stivers \& Sidnell, 2016). She is doing make-believe play by animating the voice of the sheep (Line 1) and by moving the sheep figure as if it was walking (Line 2). As a response to this play signal, between lines 3-7, Venla is producing an emotional stance shift from neutral to smiley face (Fig. $1 \rightarrow$ Fig. 2) and from silent observation toward short bursts of laughter. With these emotional stance shifts Venla displays her understanding of and alignment and affiliation with the adult's playful stance.

If we examine the sequence from Tuuli's and Ella's perspective, we can see that their alignment and affiliation with the adult's playful stance is not that straightforward. In order to establish a play connection with Tuuli and Ella, the adult needs to do more interactional 
work. As a response to Tuuli's protest (misalignment in Line 5), the adult repeats her play signaling turn (lines 6,8$)$. This playful repetition integrated with positive emotional stance (smiling in Line 8) seems to be effective way of engaging Tuuli as she instantly responds with a smile (Line 9) and short bursts of laughter (Line 12). While smiling and laughing Tuuli is also producing coordinated gaze shifts between the adult and the sheep figure. In this way she is indicating alignment with both the ongoing play actions and the adult. In other words, Tuuli's emotion displays are happening in a shared make-believe play frame with the adult and therefore they can be seen as affiliated and not just aligned. What follows between lines 12-14 is an emotionally heightened moment of play connection between the adult and Tuuli as they share a mutual gaze and escalated emotional stance of joy.

If we then look at how Ella's alignment and affiliation is constituted in lines 11-13, we can see that peer interaction is meaningful in this process. Fig. 2 and Line 11 together show that Ella is first observing and eventually talking about the make-believe character with a neutral face. She is aligned with the joint play but not yet emotionally or playfully affiliated. In Line 13 Ella's emotional stance changes as she aligns and affiliates with Tuuli's laughter first by interrupting her own speech and shifting her gaze to Tuuli (Line 11) and then by beginning to laugh with Tuuli (Line 13, Fig. 3) and finally shifting her gaze to the toy figure. These actions indicate that Ella is doing make-believe play with the others.

In summary, lines 13-14 demonstrate a moment of emotionally heightened joint make-believe play as Venla's, Tuuli's, Ella's and the adult's shared and escalated emotional stances of joy are displayed in overlap. Sequentially this emotionally heightened moment is organized through the adult's lead, Venla's following, Tuuli's misalignment and eventual following and Ella's following of Tuuli's actions. These observations suggest that emotionally heightened joint play during whole-group gatherings is a highly complex activity which involves adult-child dyadic interaction, adult-group interaction and peer interaction. 
All these interactional elements are important and meaningful in making the situation what it becomes.

In Line 15 right after the emotionally heightened moment the adult leads the children from joint play back to sing-along activity. This activity shift provides an emotional stance shift from heightened joy towards a more neutral emotional stance (Fig. 4). The children align and affiliate with this more neutral style. They engage mostly in observing and listening to the adult's singing. Some of the children try to participate in singing by producing some key words and song-related hand signs with the adult.

All in all, Extract 1 forms a particular sequence, the second of a kind during the circle time, in which the joint play interaction and heightened emotional involvement is not taken further than brief constitution of a play connection. This repetitive pattern raises the question of the purpose of these brief moments of joint play. What shape will play take as the interaction unfolds? What do these play signals mean from the perspective of more sustained joint play interaction? Is it relevant or even possible to develop these brief moments of joyful play connection towards sustained co-participation in play when the interaction is happening in the context of whole-group activity? As we continue to examine the unfolding interaction we can see that the adult's choice to constitute these brief moments of play connection is a meaningful one also from the perspective of more sustained emotionally heightened joint play interaction.

\subsection{Progression of emotionally heightened joint play}

In Extract 2, right after the group has finished their song about the sheep character, Tuuli frames the interaction back to the joint make-believe play by interrupting the adult and commenting on the sheep character's feelings (Line 4). Before Tuuli's play signal, in Line 2, the adult was engaged in repairing the interaction between Sylvia and Tiia as Tiia had 
accidently flung her arm into Sylvia's face during the sing-along and Sylvia was annoyed about it. The adult's utterance was designed to neutralize the emotional stress that was hearable in Sylvia's voice and observable from her face (Line 1). However, when Tuuli begins to speak the adult interrupts her own speech and gives space for Tuuli's contribution. Tuuli's play signal contains a heightened emotional stance which creates emotional stance shift in the situation and leads participants towards more sustained, emotionally heightened joint play activity (a total of $1 \mathrm{~min} 45 \mathrm{~s}$ ).

\section{Extract 2.}
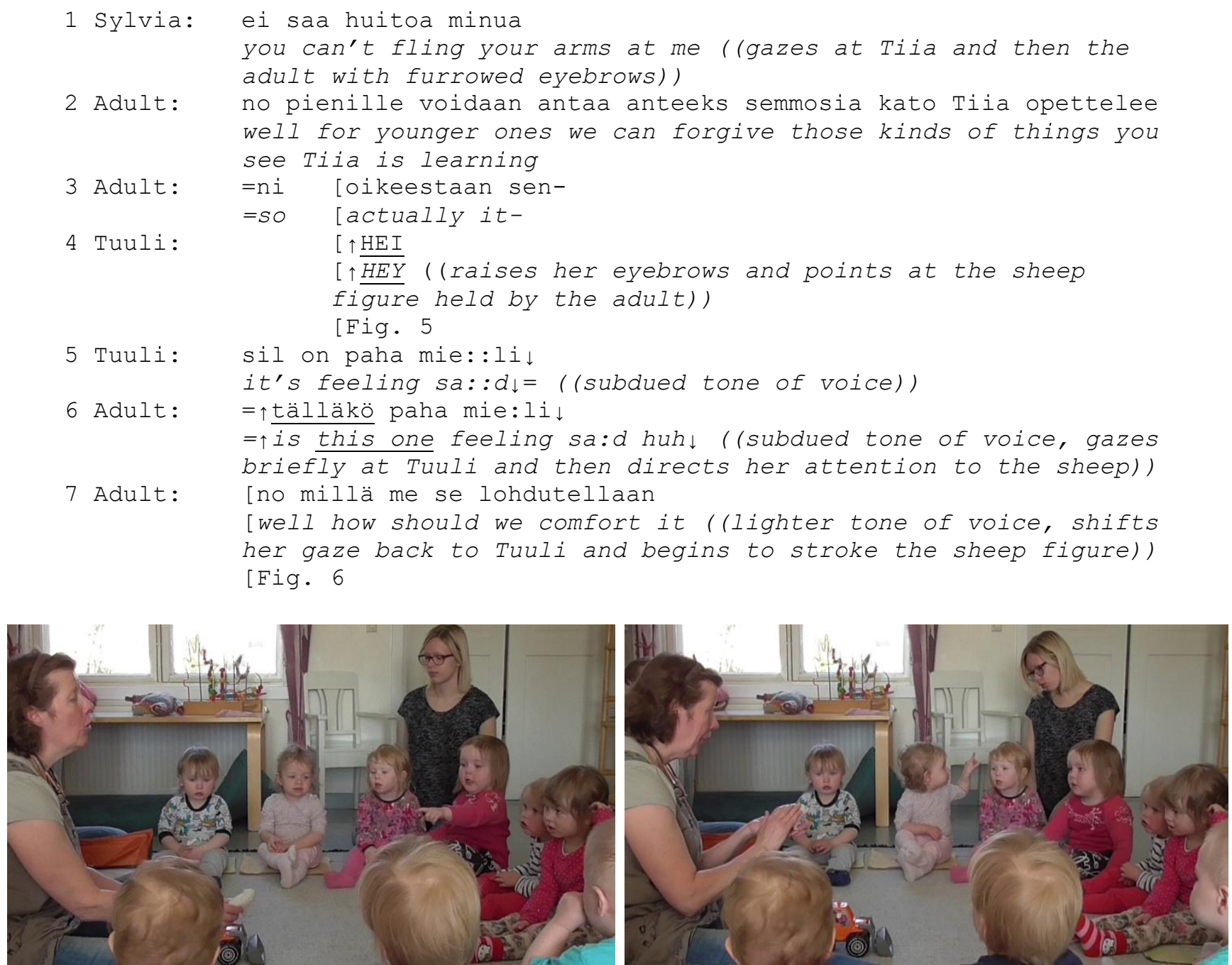

Fig. 5 \& 6. Tuuli's play signal and the adult's contribution to joint play 
Lines 4-5 show that Tuuli's play signal is highly multimodal and the verbalization is intertwined with the play itself. By gazing and pointing at the toy figure and simultaneously summoning 'HEY' with a raised voice and raised eyebrows Tuuli is using multimodal means to attract others' attention (Line 4, Fig. 5). Then in Line 5, by commenting on the sheep's feelings ('it's feeling sad'), she is re-establishing the playful stance and contributing to the adult's initial play signal (see Extract 1).

From the perspective of emotional stance taking, Tuuli's play signal is very complex and multidimensional. First, there is audible haste in the way she rhythms her speech (overlap with the adult's utterance) indicating heightened affective involvement and a sense of urgency especially in the beginning of her utterance ('HEY, it's...'). Second, she is using verbal resources to specify a particular emotion (sadness) and in this way making the imagined emotional stance of the sheep figure publicly available. Moreover, when she gets to the point of naming the emotional stance of the sheep she lengthens the vowels and lowers her pitch (subdued tone of voice). In this particular sequential place, this prosodic feature is interpretable as an expression of sadness for the sheep figure and thereby as act of doing sympathy in joint make-believe play frame (cf. Couper-Kuhlen, 2009).

In Line 6 play connection and emotional reciprocity between the adult and Tuuli become visible as the adult responds by aligning and affiliating with Tuuli's playful and emotional stance. By checking the reference ('is this one feeling sad huh' and simultaneously shifting her gaze to the sheep), the adult is working to establish a shared understanding and mutual play frame. Moreover, by lowering her pitch while producing this response (subdued tone of voice), the adult is aligning and affiliating with Tuuli's emotional stance (i.e. prosodically mirroring Tuuli's turn), and in this way, is indicating shared understanding of the joint make-believe play and the emotions it invokes. Notably, in this play signal $\rightarrow$ response sequence, shared emotional stance shifts do not have joyful underpinnings. Instead, 
shared make-believe play invokes feelings of collective sympathy towards an imagined feeling of sadness.

The way the adult contributes to Tuuli's playful stance is also interesting. In Line 7 (Fig. 6), by asking 'well how should we comfort it' and simultaneously beginning to stroke the sheep, the adult is modulating the sympathetic stance towards a lighter and somewhat hopeful tone. She is eliciting a compassionate act by expressing a need to find comfort and relief when someone is feeling sad. In this way the adult constitutes herself as particular kind of moral actor in the joint play activity. Rather than asking, for instance, why the sheep might be feeling sad, she decides to make an activity shift (Björk-Willén, 2012; Goodwin, 2002) from doing sympathy to providing comfort and compassionate next steps. The adult's contribution shows that the emotional underpinnings of play are in the hands of the participants and that interaction can unfold in a variety of ways. Both adults and children can act to escalate and prolong the matter at hand or to de-escalate and make emotional and playful stance shifts.

Taken together, the adult's response is constructed of a stance-following part (Line 6) which aligns to Tuuli's emotional and playful stance, but also of a stance-leading part (Line 7) which contributes to Tuuli's initial play signal by expanding and modulating the play frame. Thereby, the adult is not just acknowledging and aligning with Tuuli's play actions and emotional displays; she is also adding new elements to the play and to emotions that the play invokes. Thereby her contribution is additional and aims to express her own stance (particular moral orders) alongside the child's stance (act of sympathy).

As the joint play interaction continues, playful and emotional stance taking expands towards collaborative treatment of emotions in a sustained, shared make-believe play frame. Extract 3 directly continues from Extract 2 . In it, the adult and Tuuli take turns to further elaborate the imagined emotional stance of the sheep figure, creating sustained co- 
participation and complex emotional involvement in their joint play. Most of the other

children actively witness this exchange by aligning to the on-going activity with their head movements and gaze shifts. Some of the children also show affiliation with their facial expressions.

\section{Extract 3.}

7 Adult: no millä me se lohdutellaan

well how should we comfort it (lighter tone of voice, shifts her gaze back to Tuuli and begins to stroke the sheep))

8 Tuuli: se haluu $\uparrow$ äi: :tiä

it wants its $\uparrow$ mo: :mmy ((subdued tone of voice, gazes at adult then at the sheep figure and again at the adult))

9 Adult: no nii:n haluais (.) se huutaa et well ye:s it does (.) it's shouting ((subdued prosody, gazes at the sheep figure))

10 Adult: [ä^iti: : $\downarrow$ missä $\uparrow^{\circ} \circ l e:: t^{\circ} \downarrow$

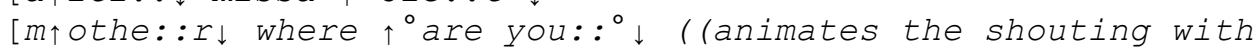
sing-song like prosody, shifts her gaze to Tuuli, and

simultaneously strokes the sheep figure))

11 Tuli: [( shares mutual gaze with the adult, then coordinates her gaze between the adult and the sheep figure))

12 [(lalso other children are coordinating their gaze between the adult and the sheep figure, some of the children are making sad faces by frowning))

[Fig. 7

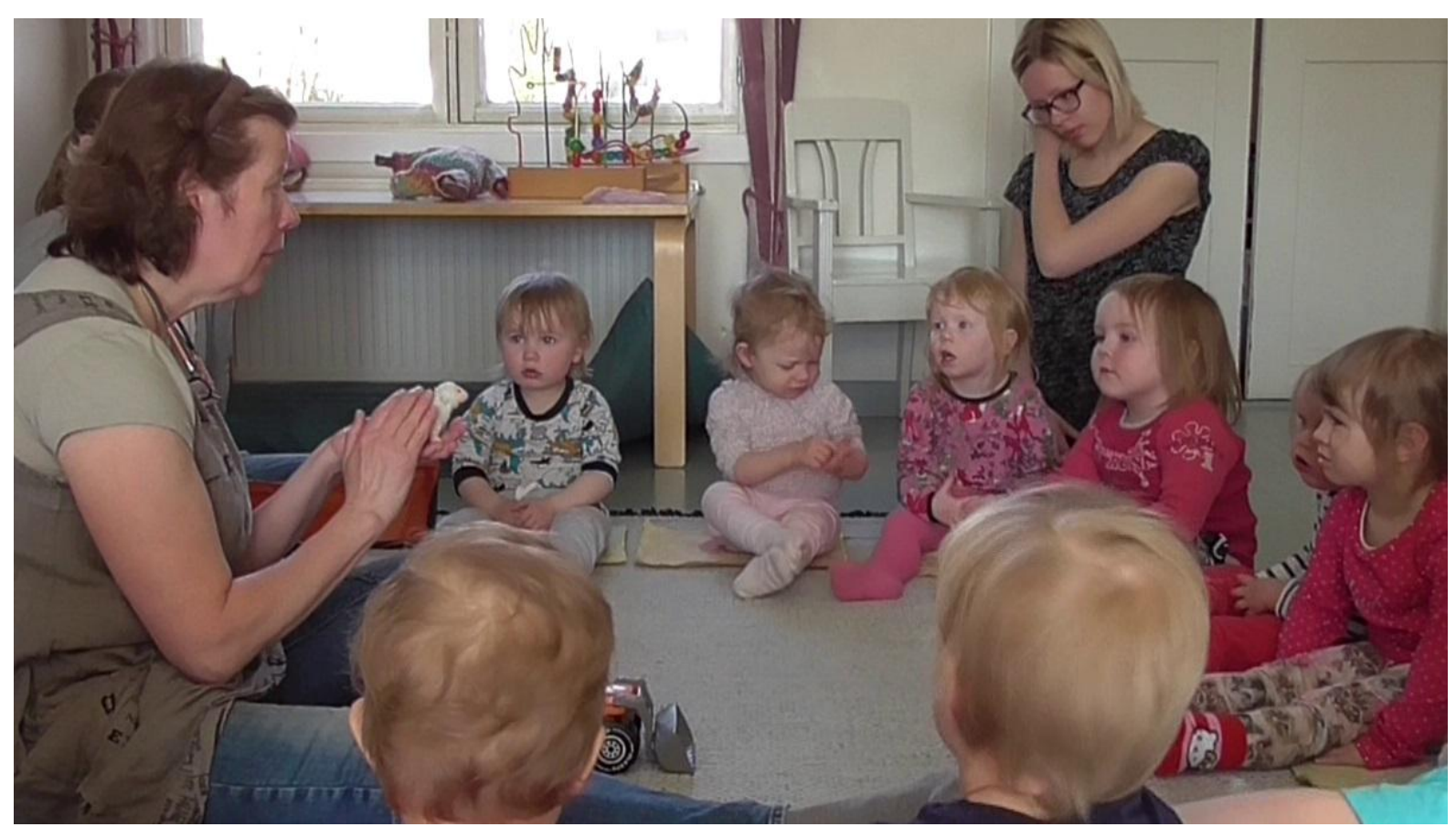

Fig. 7. Emotionally heightened moment in joint play activity 
In Line 8 Tuuli is aligning with the joint play activity. However, her affiliation with the adult's stance-leading act (i.e. finding relief and comfort for the sadness) is ambiguous. Whether Tuuli is reporting a state of affairs that explains the sheep figure's sadness or providing information about what could comfort the sheep is not publicly available in the situation. In any case, by saying 'it wants its mommy' Tuuli modulates the imagined emotional stance of the sheep by adding new emotional nuances of longing to the initial feeling of sadness, and in this way produces another stance-leading act in joint play. Her tone of voice stays subdued and whining, marking her own emotional stance here and now as display of sympathy. The topic of 'wanting' or missing one's mommy is hearable as young children's real-life experience in a group-care context, identifying the seriousness that children bring to their play (Bateman et al., 2013). It seems that Tuuli's play act opens up a space for personal reflections on the emotionally heightened real-life trajectories (sadness and longing when mother is gone) in a shared make-believe play frame.

The adult treats Tuuli's play act as explanation of the sheep figure's sadness and expresses understanding of and alignment and affiliation with this interpretation. In Line 9, the adult first receives the new information by aligning to it, agreeing 'yes it does'. Subdued prosody indicates affiliation, that is, the adult is sharing the emotional stance of sympathy with Tuuli. Then, in Line 10, she provides her own contribution by animating the shouting and longing of the sheep. At this point the lighter and somewhat hopeful tone that there was in the adult's voice at the end of her previous utterance in Line 7 has disappeared, giving way to expressions of sympathy (Line 9) and finally to illustrations of sadness and longing (Line 10). The adult's animation is designed to depict an actual yelling of the play character and is therefore an enactment of imagined talk in which the speaker temporarily lends his or her voice to another, in this case to a play character (indirect voicing, i.e. playing through a toy figure, Sawyer, 1997). The longing and sadness are prosodically marked as such by 
lengthening the vowels, and by using a subdued tone of voice. However, other features also regulate and create distance to these emotions. The adult rhythms her speech with a risingfalling intonation that sounds like sing-song prosody, which contains or hides the real-life displays of sadness. There is also little down-regulation of feelings of sadness and longing in the way the adult softens her voice at the end of her utterance. It seems that this duality of emotional underpinnings marks the fact that this is play not real.

With this playful animation, the adult is following Tuuli's lead and illustrating her own understanding of Tuuli's playful and emotional stance. This kind of stance-following turn can be treated as giving the prior speaker Tuuli more room to speak. In other words, the adult is engaged in a strategy of recipient design, listening for how the child wanted to be heard and designing her own turn to show this pattern (Danby, Barker \& Emmison, 2005; Sacks, 1995). This is done with a firm gaze directed at Tuuli, indicating the willingness to pass the turn to talk back to her. The adult seems to be signaling: 'I see that this is the thing that you want elaborate further and express emotion about, let me give you some more room to engage with it and tell us about it.'

From the perspective of emerging group processes, we can see that the adult's turn creates an invitation to heightened emotional involvement and shared engagement for the whole group. Our observations of the children's attentive facial expressions, intense gaze directed towards the toy figure and displays of heightened emotional involvement such as frowning (Line 12, Fig. 7) confirm how this contribution serves the facilitation of shared engagement and heightened emotional involvement on a group level. This animation of sadness and longing makes the imagined emotional stance of the sheep figure hearable and in this way more available for the whole group. 
In a continuation of Extract 3, the elaboration of the sheep figure's sadness and longing (Tuuli's lead) begins to interweave with the mission to find comfort and relief (the adult's lead) and the following sequence occurs:

\section{Extract 4.}

13 Adult: minä kurkkaan tänne

I'll check over here (lighter tone of voice, peeks inside the barn looking for the mother sheep, but cannot find it))

14 Adult: tiedättekö mitä (.) hỵ (.) nyt meidän täytyy sitä lohdutella lisää kato ku sen äiti on lähteny töihin ei näy koko navetassa you know what (.) uh (.) now we have to comfort it even more ((strokes the sheep)) because its mom has gone to work ((shifts her gaze to Tuuli)) (.) she's not in the barn ((shakes her head))

15 Adult: joutuu sanomaan sille että= we have to say to it that ((shifts her gaze to the sheep and extends her head closer to it))

16 Adult: =he:i:: täällä hoidetaan hyvin (.) äidit tulee iltapäivällä =he:y: : you'll be treated well here (.) mothers will come back in the afternoon ((in a soft, warm and caring voice))

17 Adult: mitähän se siitä tykkää what is it gonna think about that (lighter tone of voice, shifts her gaze to Tuuli))

18 Ella: äiti lammasta

mom sheep

19 Adult: no niinpä well yes exactly ((shifts her gaze to Ella))

20 Tuuli: se itkee: kun äiti

21 Adult: it'll cry: when mom

tulee

[ comes back $[($ nods $))$

kyllä se saattaa itkeäkin ja sit meijän täytyy vielä sitä lohdutella ja sanoa että-

Yeah it might cry a bit and we have to comfort it and say that-

23 Adult: =mitähän me sille ruuaksi annettais jos sen on nälkä

what should we feed it if it is hungry

(lthe adult and the children begin to elaborate further the question of what to feed the sheep))

New playful and emotional elements emerge in the play as the adult cannot find the mom sheep (Line 13). As a consequence, the 'easiest' and most evident way to find comfort and bring the emotionally heightened play sequence to a close is not available and the adult needs to spontaneously invent her next play move in order to secure the progression of play. In Line 14, the adult ties young children's real-life trajectories and experiences to the play as she states that 'mom has gone to work.' This kind of tying explicates the idea that the sheep 
figure's feelings and ongoing make-believe play could be some sort of representation of the children's real emotional lifeworld and in this way identifies the seriousness that the adult brings to the play (explicit referencing, Bateman et al., 2013).

When the adult gets to this culmination point she softens her message by producing a softer and lighter tone of voice and, with this emotional stance shift, signals that this is still play. She also provides emotional support in the subsequent turn (Line 16), using comforting speech with heightened emotional involvement (intense voice, vowel lengthening, extending her head closer to the sheep). At this point she works in some sort of dual role as she takes on the role of an adult but still works inside the make-believe play. Her question in Line 17 activates the children to participate verbally.

Lines 18-20 reveal that this open-ended question actually works to facilitate the children's verbal participation. In Line 19 Tuuli demonstrate her willingness to take deeper look to the feelings of sadness as she contributes to the play by verbalizing actions that describe the emotional stance of the sheep ('It'll cry'). Interestingly, she ties the crying to the reunion, to the moment when mother comes back. However, the adult's subsequent turn in Line 20 does not elaborate Tuuli's scenario further. Instead, the adult performs an aligning turn (Line 22) and then an activity shift. By taking the lead the adult frames the interaction towards a new theme, finding food for the sheep.

As Extract 5 will reveal, this activity shift is also a kind of tying as the institutional structure of the day guides the adult to orient to the forthcoming lunch time and closing the circle time. By tying the sheep figure's situation to the real-life situation of the group, the adult thematically bridges the gap between circle time and lunch time. In the next subsection we will analyze how the joint-play sequence is closed and how the adult's actions ensure that play is still present in the transition phase from circle time to lunch time. 


\subsection{Closing the emotionally heightened play sequence}

In this subsection, one further excerpt is presented in order to demonstrate how the joint-play sequence is closed and how the activity shift from play to real-life activities (transition to lunch time) is organized. The following excerpt illustrates the closing of the emotionally heightened play theme. Before this closing sequence the adult had repeated her question of 'what should we feed it if it is hungry' (see Extract 4, Line 23) a couple of times in slightly different verbal forms, without getting any aligning and affiliating answers that would solve the issue and possibly close the play sequence. As the adult begins to produce her own solutions to the feeding question in Line 1, Tuuli interrupts her and provides an aligning and affiliating play act (Line 2) that closes the emotionally heightened play theme and helps the adult to make an activity shift from play to the forthcoming lunch time (Line 8).

\section{Extract 5.}

1 Adult: heinäähän ne muten syö tietenkin lampaat mutta katotaan-

of course sheep do eat grass after all but we'll see-

2 Tuuli: =se haluaa syödä tota heinää

it wants to eat that grass ( points behind the adult at a wall

that has a picture of a Moomin house with a lawn))

3 Adult: hei no mut sehän ois aika ihana ajatus

hey that's a wonderful idea

4 Adult: kato tuolla ois meillä Mumitalon heinät jos sä sieltä ottaisit vähän

look we have a lot of grass over there at the Moomin house if you wanted to take some of that (lanimates the telling and extends her face closer to the sheep))

5 Adult: [Tuuli (.) mahtava ajatus

[Tuuli (.) that's a great idea

6 Tuuli: $\quad[($ (nods) $)$

7 Adult: oikein hyvä minä luulen että lammas tulee siitä hyvälle tuulelle=

very good I think the sheep will be glad=

8 Adult: =ja sit me voidaan- laitetaan traktorit pois ja kuunnellaan vähän että mitäs me tänään-

=and then we can- Iet's put tractors away and let's hear what we today-

9 Tuuli: $\overline{=}$ e haluu noi heinät tonne

it wants those grasses over there ((points at the barn))

10 Adult: no katotaan sehän voi haluta kaikennäköistä mut mä en aina anna kaikkee mitä pienimmät lampaat haluaa et jos haluaa muumitalon heinät laittaa sinne tota navetan sisälle ni siel voi tapahtuu muutaki hassua 
well let's see it might want this and that but I won't always give what the smallest sheep want so if one wants to put the Moomin house grass inside the barn, something else funny can happen there as well (directive and slightly irritated tone of voice))

11 Adult: mut heinää mä voin sille kyllä antaa= but grass I can give to it=

12 Adult: =mut hei tänään syödään

but hey today we are going to eat (ldirective but also softer and more friendly voice))

13 [ (lthe adults are reporting what they are going to eat today by naming and making signs for the food items, some of the children are participating by emulating the signs)) [Fig. 8

14 Adult: 'mennään syömään kalakastiketta (.) mennään syömään perunaa 'let's go and eat fish sauce (.) let's go and eat potatoes ${ }^{\circ}$

15 Adult: ja koska ne ei oo lampaiden herkkuja ni lammas saa mennä syömään tuota ruohoa

and because the sheep doesn't like to eat those, so the sheep can go and eat the grass ((shifts her gaze to the sheep))

16 Adult: [kysytään muumitalosta vielä että saako sinne yks pieni lammas tulla sinne lammastarhaan

[let's ask somebody at the Moomin house if it's okay for one little sheep to visit their sheep garden (lgets up from the floor and fastens the sheep on the wall next to the picture of Moomin house and lawn))

17 Tuli: [( walks toward the lunch hall, while walking shifts her gaze to the adult and stops to observe as the adult fastens the sheep on the wall))

[Fig. 9
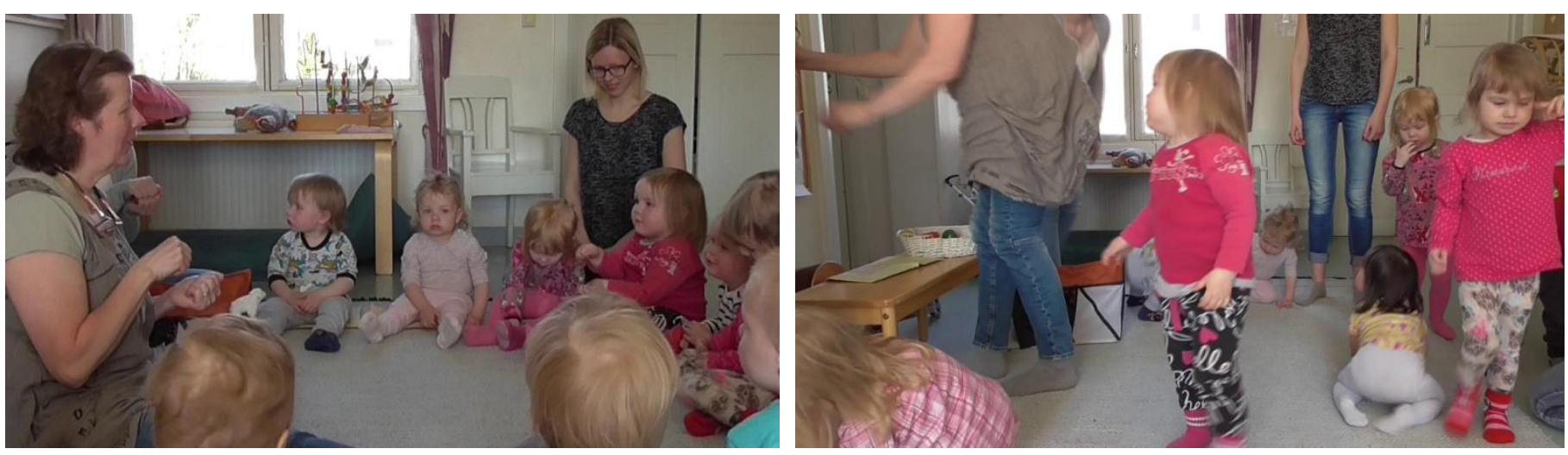

Fig. 8 \& 9. Tuuli's alignment with the adult's institutional regulation and final closing of the joint play

As we can see from lines 8-11, the activity shift is not unfolding as smoothly as the adult's turn in Line 8 suggested. In Line 9 Tuuli interrupts the adult and displays her willingness to continue the joint play. As a response in Line 10, the adult aligns with Tuuli's play signal and interrupts her ongoing activity. She builds on what Tuuli had begun, but displays disaffiliation with Tuuli's play suggestion (see also negating, 'saying yes, but' 
Lobman, 2006). By taking the lead and regulating the situation from an institutional perspective, she constitutes herself as particular kind of moral actor in the joint play activity and shows that there are also boundaries in the children's participation. With a directive and slightly irritated voice, she signals that this is not the place to interrupt the ongoing activity. The adult is tying real-life trajectories to the play situation, by explicating the asymmetrical power relations between adults and children ('I won't always give what the smallest sheep want'). As she continues her turn in Line 11, she keeps her voice directive but makes an emotional stance shift from irritation to more friendly tone. By making an activity shift from play to reporting on today's lunch without any break she displays disaffiliation also with the progressivity of the joint play (i.e. not providing Tuuli with an opportunity to contribute anymore). In Line 13 (Fig. 8), Tuuli displays acceptance (both alignment and affiliation with the adult's activity shift) as she actively participates to the reporting activity by emulating the signs together with the adults and some other children.

Interestingly, the adult makes a final shift back to the make-believe play after the group has begun their transition from a circle area to a lunch hall (Line 14-17). In Line 16, after getting up from the floor, the adult fastens the sheep figure to the wall next to the picture of the Moomin house and lawn and simultaneously verbalizes her final play contribution. If we observe the adult's actions in isolation this shift back to the make-believe play seems to be a secondary activity alongside the transition without clear communicative intentions (Fig. 9, the adult is facing the wall). However, Fig. 9 and Line 17 together show how Tuuli witnesses and thereby participates in the situation. Rather than a side activity, this sequence is therefore an important closing of the emotionally heightened joint play between the adult and Tuuli.

These observations remind us that adults can do a great deal for the children's play with small and mundane things. Although the adult does not notice how Tuuli witnesses the 
play situation, the sequence reveals the importance and emotional value of the play and its proper closing for Tuuli. Thereby, from Tuuli's perspective, lines 10-17 can be interpretable as some sort of problem-remedy sequence. After adult's strong negating (Line 10), Tuuli is able to constitute a play connection and final closing of the joint play in concert with the adult. In summary, the emotionally heightened moments that the play provided have made something from Tuuli's emotional lifeworld publicly available and shareable for the whole group, for the adults and for herself.

\section{Concluding discussion}

In this paper, we have explored the domain of emotions as they emerge in joint play activity between adults and very young children in a natural group-care setting. Drawing on the sequential perspective of CA, we have offered a detailed empirical micro-analysis of a single case in which emotionally heightened joint play was created, maintained and closed between adults and children during whole-group circle time. The analysis revealed that shared playful and emotional stance taking created possibilities for children and adults to explore personal reflections of the emotionally heightened real-life experiences in a shared make-believe play frame (cf., Bateman et al., 2013).

More specifically, children and adults used make-believe play as a site for exploring emotionally stressful everyday trajectories (children missing their mothers who have gone to work) and a wide range of emotional underpinnings that were related to these trajectories (sadness, longing, escalation of negative emotions, sympathy, compassion). The fact that these experiences could be shared through joint play during circle time showed the value of play as a form of emotional sharing and understanding between adults and children in pedagogical relationships. Lending support to Björk-Willén's (2012) findings on social play and its interactional potential in peer groups, this case study further demonstrates how joint 
play can also become an important interactional and emotional resource, enabling adults and children to create a complex social and emotional order where real-life relationships are negotiated and explored through a make-believe frame.

During this emotional exploration the adult, as play partner, guided children to come to terms with emotionally stressful situations and provided emotional cues as to how stressful events might be faced and managed. In this way the joint make-believe play "became a socioemotional resource to 'do' supportive relationships" and demonstrate care and compassion (Bateman et al., 2013, 24). These findings challenge the view of play as mainly children's own activity (the passive adult role of facilitator of child-directed play, for an overview see Pyle, DeLuca \& Danniels, in press; Sutton-Smith, 1990) and position adults as more accountable for contributing to the creation and sustainment of joint play interaction and emotional exploration in a group-care setting. The findings also clarify the complexity of adults' play practice. In the sequence we analyzed, the adult calibrated her participation between stance leading (Extract 1), stance following (Extract 3) and leading by following (Extract 2). The adult was flexible with these different entities, not restricting herself to one of them alone, but constructing and modulating participation turn by turn in its interactional context. Through this interactional calibration the adult was able to lend support to children's voices (Extract 3), display her own voice (extracts 1 and 2) and regulate and redirect the play situation by executing institutional voices (Extract 5).

From interactional perspective, our analysis sheds light on how co-coordinated emotional stance shifts might have certain interactional purposes and functions in the sequential organization of joint play. Our observations suggest that the emotional underpinnings of play cannot be reduced to certain emotional states as static entities (e.g., joy, fun) or spontaneous emotional responses to others' behavior. Rather, co-coordinated, delicately timed emotional stance shifts as dynamic interactional processes create the publicly 
available, shared experience of joint play. Thereby, emotional stance shifts during a play connection can be understood as interactively ordered signs of togetherness (Hännikäinen, 2001) and shared understanding (alignment and affiliation, Stivers, 2008).

The analysis further suggests that the interplay of emotional and playful stance taking in make-believe play produces emotional transitions in interaction (Kaukomaa et al., 2015). These transitions can be understood as interactional accomplishments that offer children and adults the possibility to align and affiliate themselves with their own and each other's emotional experiences and real-life trajectories in a shared make-believe play frame. According to our observations, it seems that during sustained play interaction more complex chains of emotional transitions and emotional investments are organized. It may be that an established play connection enables greater variation of emotional stances and continuation of play, although play signals are emotionally more complex, heightened, reflective and even ambiguous (Kuczaj \& Horback, 2013).

These ideas have a profound impact on both the pedagogical aspects of play situations and the activity of the adult. If the interaction requires an extended play session in order to evolve from brief, cheerful bursts of laughter (moments of play connection) into a varied and in-depth examination and sharing of different kinds of emotional stances and experiences, the primary objective of the adult should be to ensure the longevity of the play interaction in the group-care context. In this way joint play between adults and children can develop as "a valuable resource for opening up possibilities to explore painful events, and to grapple emotionally with difficult issues" (Bateman et al., 2013, 25). This should not to be taken to mean that ECE practitioners should engage in therapeutic sessions with children. Rather it shows the inherent emotional potential of spontaneous everyday play activities through which it is possible for adults to support children's resilience (Bateman et al., 2013; Haight, Black, Ostler, \& Sheridan, 2006). 
We suggest that adults working in ECE need to construct understanding of play as joint activity in which playful and emotional stance taking are intertwined and simultaneously involved. In this way play activity in group-care settings can expand towards an important interactional and emotional resource between adults and children. These pedagogical implications present a potential future scenario in which play could be construed not only as every child's right, but also as adults' professional competence and emotional work (cf. care as emotional/affective labor, Taggart, 2011; Kostogriz, 2012). Based on our empirical observations we also suggest that different forms of participation - leading, following and leading by following - can function as a pedagogical framework for adults in play and help adults to calibrate their participation more sensitively in situ.

All in all, this study has sought to understand play in an ECE setting from both children's and adults' perspectives at the same time. The play sequences analyzed here were in an aligning and mostly in affiliating relationship, so further research is required to explore instances of stance taking in a non-aligning and non-affiliating relationship. This could reveal problem-remedy sequences in play more evidently and enrich the understanding of the (re)establishment of play connection between adults and children. If we want to understand what constitutes sustained joint play between adults and very young children, it is important to examine not only the congruent patterns of their joint interaction but also their play actions in the light of misunderstandings, incongruent responses and problem conduct. In a natural group-care setting for under-threes, where play is typically fragmented and a lot of side activities affect the coherence of the interaction (Singer, Nederend, Penninx, Tajik \& Boom, 2014), deeper knowledge of problem-remedy sequences are relevant for further development of ECE theory and practice. 


\section{Acknowledgments}

We wish to thank all the children, parents and ECE practitioners who participated in the study. Many of the ideas for this paper originated in data sessions for the Intersubjectivity in Interaction project. We are grateful to Anssi Peräkylä and other members of the Emotion team for sharing their views and ideas. For her comments and discussions, we are most grateful to Marjatta Kalliala.

Declarations of interest: none.

This research did not receive any specific grant from funding agencies in the public, commercial, or not-for-profit sectors.

\section{Appendix. Transcription conventions}

Based on Jefferson (2004).

[ ] Brackets indicate overlapping talk/nonverbal actions

$\uparrow \downarrow \quad$ Arrows indicate shifts into especially high or low pitch

: $\quad$ Sound or nonverbal act before colon is stretched

word Underlining indicates stress/emphasis

WORD Loud volume

${ }^{\circ}$ word $^{\circ} \quad$ Quiet voice relative to the surrounding talk

A dash indicates a cut-off

$=\quad$ No break or gap between or within turns

(( )) Words in double brackets are descriptions of nonverbal actions 


\section{References}

Aronsson, K., \& Thorell, M. (1999). Family politics in children's play directives. Journal of Pragmatics, 31(1), 25-48.

Bateman, A. (2015). Conversation analysis and early childhood education: The coproduction of knowledge and relationships (Doing pretend play, 4, pp. 41-66). Hampshire: Ashgate/Routledge.

Bateman, A., Danby, S., \& Howard, J. (2013). Living in a broken world: how young children's well-being is supported through playing out their earthquake experiences. International Journal of Play, 2(3), 202-219.

Bateson, G. (1976). A theory of play and fantasy. In J. S. Bruner, A. Jolly, \& K. Sylva (Eds.), Play - Its role in development and evolution (pp. 119-129). Harmondsworth: Penguin Books Ltd.

Björk-Willén, P. (2012). Being doggy: Disputes embedded in preschoolers' family role-play. In S. Danby \& M. Theobald (Eds.), Disputes in Everyday Life: Social and Moral Orders of Children and Young People (Sociological Studies of Children and Youth, 15) (pp. 119-140). Bradford: Emerald Insight.

Burghardt, G. M. (2005). The Genesis of Animal Play. Cambridge: MIT Press.

Burghardt, G. M. (2011). Defining and Recognizing Play. In A. D. Pellegrini (Ed.), The Oxford Handbook of the Development of Play (pp. 9-18). New York: Oxford University Press.

Butler, C. W. (2008). Talk and social interaction in the playground. Hampshire: Ashgate. Couper-Kuhlen, E. (2009). A sequential approach to affect: The case of "disappointment." In M. Haakana, M. Laakso \& J. Lindström (Eds.), Talk in interaction-Comparative dimensions (pp. 94-123). Helsinki, Finland: SKS Finnish Literature Society. 
Cobb-Moore, C. (2012). 'Pretend I was Mummy': Children's production of authority and subordinance in their pretend play interaction during disputes. In S. Danby \& M. Theobald (Eds.), Disputes in Everyday Life: Social and Moral Orders of Children and Young People (Sociological Studies of Children and Youth, 15) (pp. 85-118). Bradford: Emerald Insight.

Danby, S., Barker, C., \& Emmison, M. (2005). Four observations on opening calls to Kids Help Line. In C. D. Baker, M. Emmison \& A. Firth (Eds.), Calling for help: Language and social interaction in telephone helplines (pp. 133-151). Amsterdam/ Philadelphia: John Benjamins Publishing Company.

Darwin, C. (1872/1965). The Expression of Emotions in Man and Animals. Chicago: Univ. Chicago Press.

Du Bois, J. W. (2007). The Stance Triangle. In R. Engelbretson (Ed.), Stance Taking in Discourse: Subjectivity, Evaluation, Interaction (pp.139-182). Amsterdam/ Philadelphia: John Benjamins Publishing Company.

Du Bois, J. W. \& Kärkkäinen, E. (2012). Taking a stance on emotion: affect, sequence, and intersubjectivity in dialogic interaction. Text \& Talk, 34(4), 433-451.

Erickson, F. (2010). The neglected listener: issues of theory and practice in transcription from video in interaction analysis. In J. Streeck (Ed.), New adventuresin language and interaction, (pp. 243-256). Amsterdam: John Benjamins Publishing Company.

Garvey, C. (1976). Some Properties of Social Play. In D. G. Singer, J. S. Bruner, A. Jolly \& K. Sylva (Eds.), Play - Its Role in Development and Evolution (pp. 570-583). Harmondsworth: Penguin Books Ltd.

Goodwin, C. (1994). Professional vision. American Anthropologist, 96, 606-633.

Goodwin, C. (2000). Action and embodiment within situated human interaction. Journal of Pragmatics, 32(10), 1489-1522. 
Goodwin, C. (2007). Participation, stance and affect in the organization of activities. Discourse \& Society, 18, 53-73.

Goodwin, M. H. (2002). Building power asymmetries in girls' interaction. Discourse and Society, 13(6), 715-730.

Goodwin, M. H., Cekaite, A. \& Goodwin, C. (2012). Emotion as stance. In A. Peräkylä \& M.-J. Sorjonen (Eds.), Emotion in Interaction (pp.16-42). Oxford: Oxford University Press.

Haight, W., Black, J., Ostler, T., \& Sheridan, K. (2006). Pretend Play and Emotional Learning in Traumatized Mothers and Children. In D. G. Singer, R. Michnick Golinkoff, \& K. Hirsh-Pasek (Eds.), Play = Learning: How play motivates and enhances children's cognitive and social-emotional growth, (pp. 209-230). New York: Oxford University Press.

Howard, J., \& McInness, K. (2013). The essence of play: A practice companion for professionals working with children and young people. London: Routledge.

Hännikäinen, M. (2001). Playful Actions as a Sign of Togetherness in Day Care Centres. International Journal of Early Years Education, 9(2), 125-134.

Jefferson, G. (2004). Glossary of transcript symbols with an introduction. In G.H. Lerner (Ed.), Conversation analysis. Studies from the first generation (pp. 13-31). Amsterdam: John Benjamins.

Jung, J. (2013). Teachers' roles in infants' play and its changing nature in a dynamic group care context. Early Childhood Research Quarterly, 28, 187-198.

Kaukomaa, T., Peräkylä, A., \& Ruusuvuori, J. (2015). How listeners use facial expression to shift the emotional stance of the speaker's utterance. Research on Language and Social Interaction, 48(3), 319-334. 
Kostogriz, A. (2012). Accountability and the affective labour of teachers: a MarxistVygotskian perspective. Australian Educational Researcher, 39(4), 397-412.

Kuczaj, S. A., \& Horback, K. M. (2013). Play and emotion. In S. Watanabe \& S. A. Kuczaj (Eds.) Emotions of Animals and Humans, (pp. 87-112). Japan: Springer.

Lerner, G. H., \& Zimmerman, D. H. (2003). Action and the appearance of action in the conduct of very young children. In P. Glenn, C. D. LeBaron, \& J. Mandelbaum (Eds.), Studies in Language and Social Interaction. In Honor of Robert Hopper (pp. 441457). New Jersey: Lawrence Erlbaum Associates, Inc., Publishers.

Lillard, A. S. (1993). Young Children's Conceptualization of Pretense: Action or Mental Representational State? Child Development, 64, 372-386.

Lobman, C. L. (2006). Improvisation: An analytic tool for examining teacher-child interaction in the early childhood classroom. Early Childhood Research Quarterly, 21, $455-470$.

Løkken, G. (2011). Lived experience as an observer among toddlers. In E. Johansson, \& E. J. White (Eds.), Educational Research with our Youngest: Voices of Infants and Toddlers (pp. 161-184). Dordrecht: Springer Science.

Madrid, S., Fernie, D., \& Kantor, R. (2015). Reframing the emotional worlds of the early childhood classroom. New York: Routledge.

Patton, M. (1990). Qualitative research and evaluation methods. Beverly Hills, CA: Sage Publications.

Pursi, A. \& Lipponen, L. (In press). Constituting play connection with very young children: Adults' active participation in play. Learning, Culture and Social Interaction (2017), https://doi.org/10.1016/j.lcsi.2017.12.001. 
Pyle, A., DeLuca, C., \& Danniels, E. (in press). A Scoping review of research on play-based pedagogies in kindergarten education. Review of Education (2017), DOI: 10.1002/rev3.3097.

Sacks, H. (1984). Notes on methodology. In J. M. Atkins \& J. Heritage (Eds.), Structures of social action: Studies in conversation analysis. Cambridge: Cambridge University Press.

Sacks, H. (1995). Lectures on conversation (Vol. I \& Vol. 11). Oxford: Blackwell.

Sawyer, R. K. (1997). Pretend play as improvisation: Conversation in the preschool classroom. New Jersey: Lawrence Erlbaum Associates, Inc.

Schegloff, E. A. (1987). Analyzing single episodes of interaction: An exercise in conversation analysis. Social Psychology Quarterly, 50, 101-114.

Selting, M. (1994). Emphatic speech style: with special focus on the prosodic signaling of heightened emotive involvement in conservation. Journal of Pragmatics, 22, 375-409.

Selting, M. (2010). Affectivity in conversational storytelling: An analysis of display of anger or indignation in complaint stories. Pragmatics, 20(2), 229-277.

Sidnell, J. (2011). The epistemics of make-believe. In T. Stivers, L. Mondada, \& J. Steensig (Eds.), The Morality of Knowledge in Conversation (pp. 131-155). United Kingdom: Cambridge University Press.

Singer, E. (2013). Play and playfulness, basic features of early childhood education. European Early Childhood Education Research Journal, 21(2), 172-184.

Singer, E., Nederend, M., Penninx, L., Tajik, M., \& Boom, J. (2014). The teacher's role in supporting young children's level of play engagement. Early Child Development and Care, 184(8), 1233-1249. 
Smith, P. K. (1997) Play fighting and real fighting. In A. Schmitt (Ed.), New Aspects of Human Ethology (pp.47-64), New York: Plenum Press.

Stern, D. (2004). The present moment in psychotherapy and everyday life. New York: W. W. Norton \& Company.

Stivers, T. (2008). Stance, alignment, and affiliation during storytelling: when nodding is a token of affiliation. Research on Language and Social Interaction, 41, 31-57.

Stivers, T., \& Sidnell, J. (2016). Proposals for activity collaboration. Research on Language and Social Interaction, 49(2), 148-166.

Sutton-Smith, B. (1990). Dilemmas in adult play with children. In K. McDonald (Ed.). Parent-child play (pp. 15-42). Albany, NY: SUNY Press.

Taggart, G. (2011). Don't we care?: the ethics and emotional labour of early years professionalism. Early Years, 31, 85-95.

White, E., J. (2013). Cry, baby, cry: A dialogic response to emotion. Mind, Culture, and Activity, 20, 62-78. 